\title{
The Experience of Legal Regulation of Reclamation of the Developed Space by the Leading Countries of Coal Mining
}

\author{
Irina Verchagina ${ }^{*},{ }^{,}$, Irina Kolechkina $^{1}$, and Elena Shustova $^{2}$ \\ ${ }^{1}$ T.F. Gorbachev Kuzbass State Technical University, Belovo Branch, 652644, Ilyica st. 32, Belovo, \\ Russia \\ ${ }^{2}$ Kazakh Humanitarian Law Innovative University, Semey, Kazakhstan
}

\begin{abstract}
The article presents the results of a study of the regulatory framework and the experience of regulating the issues of reclamation of the developed space of the leading coal mining countries - the United States and China. The laws of China on mineral resources and environmental protection, the US practice of creating a system for restoring disturbed space as a result of mining, are examined
\end{abstract}

\section{Introduction}

According to the international statistical agency in 2017-2018. China is the undisputed leader in coal mining $(3,236.1$ million tons of coal in 2017). Following China, the top ten leaders in terms of coal production also include India (680.5 million), the USA (639.1 million), Australia (435.9 million), Indonesia (420.0 million), Russia (333.0 million) [1]. However, in addition to the obvious socio-economic effects, an increase in coal production and industrial use carries significant environmental damage, which is currently impossible to ignore.

In 2019, the United Nations Global Environment Outlook on the Environment was published by the OOG, in which, among other things, special attention was paid to the problem of land degradation. According to the report, $29 \%$ of the world's land, with 3.2 billion inhabitants, is in a state of degradation [2]. One of the factors of land degradation in addition to aggressive agricultural technologies - is the lack of full-fledged reclamation and conservation of the developed space during mining, as well as a violation of applicable environmental laws. The accompanying consequences of mining include the negative impact not only on soil and water resources, but also on air, biodiversity of the territory and other elements of the surrounding space [3]. All this fully applies to coal mining.

At the same time, there are practically no global statistics of space violated during mining and/or coal mining. There are some data, for example, according to the Reuters news agency, in 2018 in China alone, more than 3.6 million hectares of land was used and damaged as a result of mining [4].

All countries included in the group of coal mining leaders are faced with environmental problems, the solution of which is impossible without full legal regulation. The political and

•Corresponding author: viy.77@mail.ru 
legal will of the state is always realized through specific subjects of economic and social activity, therefore, the experience of regional environmental management in coal mining territories and regions is also part of the analysis. One of the most important results of management effectiveness at the state level can be considered the level of competitiveness of the country.

\section{Materials and methods}

As the object of analysis, we chose the United States and China, since, firstly, these countries have an established history of coal mining, and therefore an impressive array of territories related to disturbed space. And, secondly, in terms of modern coal mining, they occupy a leading position.

The subject of the analysis was normative documents, data from government agencies on the topic of the study, as well as data from the World Economic Forum on The Global Competitiveness Index.

\section{Results and discussion}

Analysis of the Global Competitiveness Index of the World Economic Forum [5] shows that over the past decade, the United States on average took 3rd place in the ranking, China - 28th. It should be noted that out of 12 parameters that determine the level of competitiveness of countries, at least 6 parameters are related to environmental management: the quality of institutions, infrastructure, health, technological level, the competitiveness of companies, innovative potential.

We are interested in the legal experience of solving the problem of the worked out (violated) space in these leading coal mining countries.

In China, there are two main laws in this area: the PRC Law on Mineral Resources (adopted at the 15th session of the Standing Committee of the All-China People's Representatives of the 6th Convocation on March 19, 1986, as amended from 1996) and the PRC Law on Protection the environment of December 26, 1989 [6].

China in recent years relates to the States leading environmental pollution, but the analysis of the PRC Law on the protection of the environment is a minor punishment for violation of environmental legislation. Thus, article 35 and 36 of the Law provides for such penalties as a warning or a fine, payment of compensation for excess pollution, suspension of operations of the company. And only in the case of serious harm to public or personal property or to injury or to death of persons are conducting a criminal investigation (article 44 of the Law). Analysis of the PRC Law on mineral resources also testifies to the closer attention of the state to protect the economic rights and interests than to environmental compliance. So, Chapter 5 Legal liability provides five basic elements of the offence (articles 39-44 of the Law), including theft, looting food development of mineral resources, other property of mining enterprises illegal mining, sale of minerals. As punishment according to the composition of criminal liability. And only one of these formulations can be categorized as violations of environmental requirements - article 44 of the Law (the use of destructive methods of development, causing serious damage to fossil resources). As punishment for this article, a penalty and cancellation of permits for mining. And only in case of serious damage to fossil resources in the immediate culprits are brought to criminal responsibility under article 156 of the Criminal code of the PRC. Pay attention that in this case, the damage is understood as damage to the resources, not the environment. Regulations and order remediation in the law of the PRC is minimized. 
In general, an analysis of Chinese legislation indicates the priority of current economic interests over long-term environmental ones, the consequence of which is a severe environmental crisis in China.

In the United States until the 1970s, environmental problems of subsoil use were also not significantly reflected in either federal or regional legislation (state laws). The problems of restoring the worked-out space were regulated by the laws of individual states, which led to an inconsistent solution to this issue. For example, in Colorado in 1965, a program was launched under which coal companies were supposed to restore disturbed land on a virtually voluntary basis. However, already in the period of the 1970s, both the legal environmental legislation and the environmental management system began to take shape in the United States.

In 1970, the National Environmental Policy Act (NEPA) was signed. The range of activities covered by NEPA is quite diverse and includes making decisions on applications for permits (licenses), including for coal-mining enterprises; adoption of federal land management measures; construction of motorways and other government facilities. As part of the implementation of Section II of NEPA, the Presidential Council for Environmental Quality (CEQ) was created to monitor the implementation of NEPA. CEQ's responsibilities include: ensuring that federal agencies comply with NEPA requirements, overseeing the federal environmental protection agency - EPA (the United States Environmental Protection Agency) over the implementation of the environmental impact assessment process, issuing regulations and other guidelines for federal agencies regarding compliance with NEPA.

All federal agencies prepare special reports with environmental impact assessments, which are divided into two categories: environmental impact assessments (EIS) and environmental assessments (EA) [7]. Mineral mining, as a rule, includes an assessment of many environmentally significant factors: conservation and transportation of hazardous substances, their disposal, etc.

In 1977, the US passed The Surface Mining Control and Reclamation Act (SMCRA), primary regulatory legal act of Federal significance in the sphere of rational use of mineral resources and reclamation of mined-out space. Prior to the entry into force of this Law in the United States had accumulated more than 46 thousand Unliquidated mines and more than 85 thousand abandoned without reclamation of uranium, coal, sand and other quarries. By 2006, the restoration of $23 \%$ of all required objects, it spent $\$ 4.06$ billion, According to estimates by Congress for reclamation of all remaining $77 \%$ will require about $\$ 72$ billion.

Since the adoption of SMCRA almost 40 years ago OSMRE in the framework of the abandoned land has reached the following purposes: closed more than 43000 abandoned mines and mine shafts; removed more than 950 miles of dangerous sides coal mines and more than 3,700 hazardous water bodies; eliminated more than 129,000 acres of hazardous embankments; restored 35000 acres of streams and land; replaced by the infrastructure to more than 53000 sources of contaminated water.

Section IV of SMCRA established the AML reclamation program funded by reclamation fees assessed on each ton of coal mined. Section 402 (a) of SMCRA established a fee for reclamation for the period to 30 September 2007 in the amount of 35 cents per ton (or 10 per cent of the value of the coal, whichever is less) for coal mined on the surface, except for lignite (brown coal), 15 cents per ton (or 10 per cent of the value of the coal, whichever is less) for coal from underground mines, and 10 cents per ton (or 2 per cent of the value of the coal, whichever is less) for lignite (brown coal).

In accordance with the original law section 402 (b) of SMCRA authorized collection of reclamation fees for 15 years after the date of adoption (August 3, 1977). Subsequent legislation has reduced the rate of collection.

Collected payments are sent to the Abandoned Lands Fund and are used to restore abandoned lands and waters. Abandoned lands and waters are those that were used for coal 
mining or involved in the coal processing process, and were also left without proper reclamation work until the adoption of SMCRA on August 3, 1977.

One of the main mechanisms used by the AML OSMRE program to recover abandoned mine lands and polluted waters is to provide grants to states and tribes so that they can control the reclamation of sites within their jurisdiction. Twenty-five coal-mining states and three tribes currently receive grants each year. They are classified in terms of certification.

Non-certified states are those states that have not yet completed the full restoration of all abandoned lands. Currently, 20 states are uncertified (Alabama, Alaska, Arkansas, Colorado, Illinois, Indiana, Iowa, Kansas, Kentucky, Maryland, Missouri, New Mexico, North Dakota, Ohio, Oklahoma, Pennsylvania, Tennessee, Utah, Virginia, Western Virginia).

Certified states and tribes. Those states and tribes that have completed all reclamation and conservation programs. Currently, five states (Louisiana, Montana, Mississippi, Texas, Wyoming) and three tribes (Navajo, Hopi, Crow Tribes) are certified.

Within the framework of SMCRA, two main programs have been developed and are operating: one for regulating existing coal mines and the other for restoring the mined-out space of canned coal enterprises. In addition, the Office of Surface Mining was also created. SMCRA was the first federal environmental law to regulate a specific industry, rather than a specific type of pollution. The Abandoned Mine Land Reclamation Program (AML) is funded by fees that subsoil users pay for each ton of coal mined to restore land and water resources affected by coal mining before August 3, 1977. Open-pit coal mining started after the date of entry into force of the Law of 1977, is implemented in accordance with established environmental requirements. The Surface Mining Control and Reclamation Act was published along with rules governing the assessment and collection of reclamation fees.

From 1977 to the present, several significant amendments have been made to the legislation on remediation, which significantly increased control over subsoil users both by the state and civil society (primarily local communities).

In 2006, another set of amendments was introduced into the legislation on remediation: the collection of land reclamation payments was extended until September 30, 2021, at gradually reduced rates. The situation with environmental payments in the United States is as follows. During the financial year, subsoil users form an annual payment fund, whose states (in which there are territories related to the violated space) and indigenous tribal groups receive payments. States and tribes distribute these funds for reclamation.

The money received is distributed as follows: $50 \%$ goes to individual states and tribes of the indigenous population, $30 \%$ goes to restore spaces that were violated as a result of coal mining until 1977, 20\% goes to the federal treasury for financing in case of emergency situations, as well as to subsidize those states that need additional funding. Of particular importance in financing restoration programs is the activities of The United States Department of the Interior (DOI), the federal executive body of the US Government responsible for managing and conserving most federal lands and natural resources, as well as for administering programs related to Native Americans.

Thus, the United States has developed a certain practice of regulatory regulation and reclamation of disturbed space as a result of coal mining. It is as follows.

1. There are systems:

- AVS - an automated database and information system into which information on subsoil users, as well as on unfulfilled work or uncorrected violations, is entered:

- TIPS - workstations for processing technical information to collect geological and environmental information in the field of subsoil use.

2 There is a special practice of taking into account the interests of the indigenous local population living in the restored lands and territories, allowing certain tribes to manage abandoned land development programs on their lands without prior approval. 
3. Funds are formed at the expense of subsoil users, the funds of which are allocated for restoration of previously disturbed (before 1977) lands, and subsoil users are responsible for water pollution, for damage from subsidence of residential premises and non-commercial structures caused by underground work.

\section{Conclusion}

Direct comparisons of environmental management in terms of reclamation of the US and China developed space on the basis of the data presented are not possible, however, we assume that there is a connection between the country's level of competitiveness and the level of development of environmental management, and this relationship will be more closely in the future.

\section{References}

1. Leading hard coal producing countries in 2017, URL: http://www.statista.com

2. Global environment outlook GEO-6 summary for policymakers (UN Environment, Washington, 2019)

3. A. Ramseyer, Environmental Impact of Mining (Penguin, London, 2017)

4. M. Zhang, E. Chow, China seeks to tackle environmental damage caused by mining (CMSI, Beijing, 2013)

5. World Economic Forum (2009-2019). URL: http://www.weforum.org

6. G. H. Owens, Abandoned Mine Lands (ASMP, Canberra, 2017)

7. Office of surface mining reclamation and enforcement. URL: http://www.osmre.gov 